\title{
Effect of Quercetin on Exercise Tolerance in Experimental Hyperthyroidism in Male Albino Rats
}

\author{
MAYADA M.A. AZAB, M.Sc.; MOHAMED M. SHEBL, M.D.; REHAB E. ABO EL-GHEIT, M.D. and \\ MOHAMED M. MADI, M.D.
}

The Department of Physiology, Faculty of Medicine, Tanta University

\begin{abstract}
Background: This work was performed to study the effect of Quercetin on exercise tolerance in experimental hyperthyroidism in male albino rats.

The aim of this work is to study the effect of Quercetin on exercise tolerance in experimentally induced hyperthyroid male albino rats.

Methods: 40 male rats were divided into 4 groups 10 rats each: (I) Euthyroid sedentary (ES), (normal control) group: Received $(0.5 \mathrm{ml}$ physiological saline daily Intra-Gastric (IG) for 3 weeks). (II) Thyrotoxic Sedentary (TS), (thyrotoxic control) group: Received exogenous thyroxine (T4), eltroxin (50mg tablet) for induction of thyrotoxicosis in increasing doses $(50 \propto \mathrm{g}$ to reach $200 \propto \mathrm{g} / \mathrm{kg}$ body weight daily by (IG) administration, for 3 weeks. The rats were given $50 \propto \mathrm{g} / \mathrm{kg}$ daily during the first week, $100 \propto \mathrm{g} / \mathrm{kg}$ daily during the second week and $200 \propto \mathrm{g} / \mathrm{kg}$ daily during third week. (III) Thyrotoxic adapted (TA) group: Received eltroxin in increasing doses $(50 \propto \mathrm{g}$ to reach $200 \propto \mathrm{g} / \mathrm{kg}$ body weight daily IG) for 3 weeks, as (TS) group. (IV) Quercetin Treated Thyrotoxic Adapted (QTTA) group: Received eltroxin $(50 \propto \mathrm{g}$ to reach $200 \propto \mathrm{g} / \mathrm{kg}$ body weight daily IG) for 3 weeks, they received also quercetin at a dose of $25 \mathrm{mg} / \mathrm{kg}$, IG on alternate days throughout the experimental period. These animals received the dose of quercetin within 2 hours before submission to the Maximal Swimming Time test (MST). All animals were submitted to MST after induction of thyrotoxicosis. However, the animals of group III, and group IV were submitted to the test after performing swim session adaptation for 2 days before doing the test.
\end{abstract}

Results: At the end of the experimental period all thyrotoxic groups showed significant decrease in total body weight compared to control group, at the same time, TS and TA groups showed significant decrease in relative liver weight, relative thyroid weight, and relative epididymal pad of fat weight compared to control group, while, QTTA group showed insignificant change compared to control group, but it showed significant increase compared to TS and TA groups. All

Correspondence to: Dr. Mayada M.A. Azab, E-Mail:mmayadaazab@gmail.com thyrotoxic groups also showed significant increase in serum T3, T4 level, and significant decrease in serum TSH level compared to control group. On the other hand, all thyrotoxic groups showed a significant increase in liver, skeletal muscle MDA, and catalase compared to control group, while TA group showed significant increase in their levels compared to TS group, however it showed significant decrease in their levels after quercetin treatment. It also showed significant decrease in liver and skeletal muscle glycogen in all thyrotoxic groups compared to control group, similarly, it showed significant decrease in TA group compared to TS group, but, it showed significant increase after quercetin treatment. On the other hand, TS and TA groups showed a significant decrease in MST, while QTTA showed insignificant change compared to control group, TA group also showed significant decrease compared to TS group, while it showed significant increase after quercetin treatment.

Conclusion: We concluded that quercetin can improve exercise intolerance that occurs in hyperthyroidism through its antioxidant effect. Key Words: Quercetin - Exercise intolerance - Hyperthy-
roidism.

\section{Introduction}

DISTURBED muscle glycogen is the primary reason for decreased endurance. Biochemical changes with hyperthyroidism that would favor enhanced flux through glycolysis may account for this dependence on glycogen [1]. It has been believed that hyperthyroidism leads to oxidative damage of various organs, resulted from an increase in prooxidant to antioxidants ratio that promotes accumulation of oxidatively damaged molecules. It has been well documented that reactive oxygen species would lead to oxidative damage of biological macromolecules, including lipids, proteins, and DNA, and oxidative stress also influenced to 
the body adipocyte results in decreases of body fat masses and related body weight decreases [2] .

Liver is a major target organ for thyroid hormone with important biological and medical thyroid hormones are known as cell metabolism regulators, being associated with different biological processes. Thyroid dysfunctions are considered as the most important endocrinopathies with hyperthyroidism is recorded to be the most common endocrine disease in women [3]

Hyperthyroidism is associated with apparent exercise intolerance, although the mechanism by which they are linked is still controversial. Thyroid hormones produce an overall increase in the basal metabolism of the human body, accompanied by greater tissue oxygen consumption, owing both to vasodilation and the concomitant increase in cardiac output, which are facilitated by enhanced chronotropism and inotropism [4]. In spite of the enhanced cardiovascular support in hyperthyroidism, dyspnea and exercise intolerance are common in hyperthyroid patients. Several lines of evidence have implicated implications, and serious liver damages accompanied to the thyroid hormone imbalances regardless of hyperthyroidism or hypothyroidism

Quercetin is a naturally occurring flavonoid, with the highest antioxidant capability. Quercetin presents in significant amounts in a variety of plant foods, and has a broad spectrum of bioactive effects

Administration of antioxidants was proved to be beneficial in reversing oxidative stress produced by exercise, hypothyroidism and cold induced hyperthyroidism [2]. Deviations from normal thyroid function, and the ensuing exercise intolerance, require appropriate medical therapy to attain euthyroid status. So the purpose of this study was to monitor the potential protective effect of a naturally occurring flavonoid, Quercetin, on exercise tolerance in L-thyroxin treated male albino rats, a wellestablished experimental model of hyperthyroidism [3].

\section{Material and Methods}

\section{Animals:}

This study was carried out on 40 local strain male albino rats weighing $(150-200 \mathrm{~g})$. The rats were housed in isolated animal cages, five in each cage, in a standard animal laboratory room in
Faculty of Medicine Tanta University and had free access to water and food ad libtium all over the period of the work, and were kept at room temperature. All procedures were done according to the Ethical Committee of Tanta University. The work was done from April 2016 to Nov. 2017.

\section{Chemicals:}

- Quercetin preparation: Quercetin was obtained from Sigma-Aldrish Co as a powder and dissolved by addition of normal saline.

- Drug preparation: Each tablet of eltroxin was dissolved in physiological saline, the solution concentration was $(10 \propto \mathrm{g} / 1 \mathrm{ml})$.

\section{Study design:}

Rats were divided into four main groups: Each consisting of 10 animals.

Group I: Euthyroid Sedentary (ES), (normal control): They received $(0.5 \mathrm{ml}$ physiological saline daily Intragastrically (IG) for 3 weeks.

Group II: Thyrotoxic Sedentary (TS), (thyrotoxic control): They received Eltroxin (50 $\propto \mathrm{g}$ to reach $200 \propto \mathrm{g} / \mathrm{kg}$ body weight daily IG) for 3 weeks, $(50 \propto \mathrm{g} / \mathrm{kg}$ daily during the first week, $100 \propto \mathrm{g} / \mathrm{kg}$ daily during the second week, and $200 \propto \mathrm{g} / \mathrm{kg}$ daily during third week [7]

Group III: Thyrotoxic Adapted (TA) group: They received Eltroxin $(50 \propto \mathrm{g}$ to reach $200 \propto \mathrm{g} / \mathrm{kg}$ body weight daily IG) for 3 weeks. After induction of thyrotoxicosis these animals submitted to maximal swimming time test [8].

Group IV: Quercetin Treated Thyrotoxic Adapted (QTTA) group: They received Eltroxin $(50 \propto \mathrm{g}$ to reach $200 \propto \mathrm{g} / \mathrm{kg}$ body weight daily IG) for 3 weeks they received also Quercetin $(25 \mathrm{mg} / \mathrm{kg}, \mathrm{IG})$, within two hours before submission to the maximal swimming time test, on alternate days throughout the experimental period [5]

\section{Sample collection and analysis:}

All animals were weighed every 3 days starting one day before Eltroxin till the end of experimental period. At the end of experimental period, all animals were anesthetized by diethyl ether, then the animals were sacrificed by cervical decapitation, and blood sample will be taken for analysis of serum total tri-iodithyronine (T3), thyroxine (T4) concentration and Thyroid Stimulating Hormone (TSH) were assayed as described by Das et al., [9] 
The liver, the gastrocnemius muscle, thyroid gland, and epididymal pad of fat were dissected and weighed then prepared for determination of glycogen in the liver and skeletal muscle tissue according to the method described by Russell et al., [10], liver and skeletal muscle malondialdehyde (MDA) according to the method described by Ohkawa et al., [11], liver and skeletal muscle catalase activity according to the method described by Martin et al., [12], the relative epididymal pad of fat weights: ( $\mathrm{mg} / \mathrm{g}$ body weight) will be calculated (absolute weight $\mathrm{mg} / \mathrm{g}$ body weight at sacrifice) by the method of Johnson et al., [13] and the thyroid gland and liver relative weights ( $\mathrm{mg} / \mathrm{g}$ body weight) will be calculated (absolute organ weight $\mathrm{mg} / \mathrm{g}$ body weight at sacrifice) according to the method of Behnke et al., [14].

\section{Adaptation to water:}

The purpose of adaptation to the water was to reduce water stress without promoting physiological adaptations to physical training. The adaptation to the water environment consisted of a 10-min exposure, at a temperature of $\left(35 \pm 1^{\circ} \mathrm{C}\right)$ daily, for 2 days in a water tank (diameter, $40 \mathrm{~cm}$; depth, $70 \mathrm{~cm}$ ) [15].

\section{Exercise tolerance:}

Exercise tolerance was indicated by the maximal swimming time, that was measured as the total amount of time from the beginning of swimming with the weights until fatigue (indicated as the rats could not again return to the surface of the water 10 seconds after sinking [16].

\section{Maximal Swimming Time (MST) (acute forced swimming):}

This test was used to assess the anaerobic physical capacity under thyrotoxic condition [1].

The maximum swim time in rats subjected to acute forced swimming was measured by forcing the animals to swim against load (5\% of body weight) attached $\sim 2$ inches from the end of the tail. The swimming time (in minutes) was measured, then the animals were helped out of the water and returned to their home cage for recovery [8].

\section{Statistical analysis:}

The data were shown as the mean \pm standard deviation. Data from the study were analyzed using by one-way Analysis of Variance (ANOVA) followed by Tukey's test to assess the significance. The $p<0.05$ were considered as statistically significant. Using SPSS for windows (Version 23.0).

\section{Results}

Effect of thyroid status on body weight and relative organs weight:

Biochemical results from the present work revealed that, all thyrotoxic groups showed significant decrease in the total body weight when compared to control group, while thyrotoxic sedentary, and thyrotoxic adapted groups showed significant decrease in relative weights of liver, thyroid, and epididymal pad of fat when compared to control group. However, quercetin treated thyrotoxic adapted group, showed insignificant change when compared to control group, but it showed significant increase when compared to thyrotoxic sedentary, and thyrotoxic adapted groups. As showed in (Table 1) and Fig. (1).

Thyroid hormones levels (T3, T4 and TSH in all studied group:

As showed in (Table 2) \& Fig. (2): There were significant increase in serum T3, and T4 levels in all thyrotoxic groups, but significant decrease in serum TSH level when compared to control group.

Liver and skeletal muscle MDA and catalase levels in all studied groups:

As presented in (Table 3), Fig. (3): The result showed that all thyrotoxic groups showed a significant increase in liver and skeletal muscle MDA, and catalase levels when compared to control group. While thyrotoxic adapted group showed significant increase in their levels when compared to thyrotoxic sedentary group. However it showed significant decrease in their levels after Quercetin treatment.

Liver and skeletal muscle glycogen levels in all studied groups:

Table (4) \& Fig. (4) showed that there were significant decrease in liver and skeletal muscle glycogen levels in all thyrotoxic groups when compared to control group. Similarly, they showed significant decrease in thyrotoxic adapted group when compared to thyrotoxic sedentary group, but, they showed significant increase after quercetin treatment.

\section{Maximal swimming time in all studied groups:}

As showed in Fig. (5), the thyrotoxic sedentary and thyrotoxic adapted groups showed a significant decrease in maximal swimming time, while quercetin treated thyrotoxic adapted showed insignificant change when compared to control group. At the same time thyrotoxic adapted group showed significant decrease when compared to thyrotoxic sedentary group, while it showed significant increase after quercetin treatment. 
Table (1): Effect of thyroid status on body weight and relative organs weight.

\begin{tabular}{lllll}
\hline & Group (I) & Group (II) & Group (III) & Group (IV) \\
\hline Body weight $(g):$ & & & & \\
$\quad$ Initial weight & $169.5 \pm 8.32$ & $179.5 \pm 14.62$ & $179.5 \pm 11.17$ & $172 \pm 15.49$ \\
$\quad$ Final weight & $184 \pm 9.37$ & $104.5 \pm 10.66^{*}$ & $96 \pm 12.65 \#$ & $97 \pm 7.89 \&$ \\
Relative liver weight $(\mathrm{mg} / \mathrm{g})$ & $3.76 \pm 0.39$ & $2.21 \pm 0.31^{*}$ & $2.21 \pm 0.28^{*}$ & $3.57 \pm 0.47 \# \&$ \\
Relative thyroid weight $(\mathrm{mg} / \mathrm{g})$ & $3.11 \pm 0.203$ & $2.5 \pm 0.27^{*}$ & $2.46 \pm 0.31^{*}$ & $3.01 \pm 0.28 \# \&$ \\
Relative epididymal pad of fat weight $(\mathrm{mg} / \mathrm{g})$ & $1.43 \pm 0.12$ & $0.58 \pm 0.07^{*}$ & $0.59 \pm 0.05^{*}$ & $1.41 \pm 0.17 \# \&$ \\
\hline
\end{tabular}

$*: p<0.05$ vs. initial weight in group I.

$\#: p<0.05$ vs. initial weight in group III.

$\&: p<0.05$ vs. initial weight in group IV.

Table (2): Total serum T3 (ng/ml), T4) ( $\mathrm{g} / \mathrm{ml})$ and serum TSH (IU/ml) in all studied groups.

\begin{tabular}{lllll}
\hline & Group (I) & Group (II) & Group (III) & Group (IV) \\
\hline Total serum T3 (ng/ml). & $0.49 \pm 0.04$ & $1.52 \pm 0.06^{*}$ & $1.49 \pm 0.04^{*}$ & $1.48 \pm 0.03^{*}$ \\
Total serum T4 (T4) $(\mathrm{g} / \mathrm{ml})$. & $39.43 \pm 3.24$ & $152.34 \pm 7.23^{*}$ & $152.83 \pm 5.43^{*}$ & $149.32 \pm 3.29^{*}$ \\
SerumTSH) $(\mathrm{IUml})$. & $1.55 \pm 0.03$ & $0.55 \pm 0.07^{*}$ & $0.53 \pm 0.06^{*}$ & $0.53 \pm 0.06^{*}$ \\
\hline
\end{tabular}

$*: p<0.05$ vs. group I.

Table (3): Liver and skeletal muscle MDA and catalase levels in all studied groups.

\begin{tabular}{lllll}
\hline & Group (I) & Group (II) & Group (III) & Group (IV) \\
\hline Liver MDA (nmol/g). & $1.54 \pm 0.08$ & $2.94 \pm 0.16^{*}$ & $3.76 \pm 0.09^{* \#}$ & $2.77 \pm 0.12^{* \# \&}$ \\
Skeletal muscle MDA (nmol/g). & $0.35 \pm 0.01$ & $0.44 \pm 0.02^{*}$ & $0.52 \pm 0.04 * \#$ & $0.40 \pm 0.01^{* \# \&}$ \\
Liver catalase (U/G). & $0.021 \pm 0.0015$ & $0.034 \pm 0.0010^{*}$ & $0.039 \pm 0.0002^{* \#}$ & $0.031 \pm 0.0007^{* \# \&}$ \\
Skeletal muscle catalase (U/G). & $0.041 \pm 0.0008$ & $0.046 \pm 0.0014^{*}$ & $0.049 \pm 0.0011^{* \#}$ & $0.042 \pm 0.0012^{*} \& \&$ \\
\hline
\end{tabular}

$*: p<0.05$ vs. group I.

\# : $p<0.05$ vs. initial weight in group III.

$\&: p<0.05$ vs. group IV

Table (4): Liver and skeletal muscle glycogen levels in all studied groups.

\begin{tabular}{llllc}
\hline & Group (I) & Group (II) & Group (III) & Adapted Group (IV) \\
\hline Liver glycogen $(\mathbf{g})$ & $27.97 \pm 0.51$ & $15.45 \pm 0.68^{*}$ & $13.42 \pm 0.49 * \#$ & $19.15 \pm 1.14 * \# \&$ \\
Skeletal muscle glycogen $(\mathbf{g})$ & $3.02 \pm 0.18$ & $1.96 \pm 0.02 *$ & $1.60 \pm 0.07 * \#$ & $2.30 \pm 0.09 * \# \&$ \\
\hline$*: p<0.05$ vs. group I. & & & \\
$\#: p<0.05$ vs. initial weight in group III. & & & \\
$\&: p<0.05$ vs. group IV. &
\end{tabular}
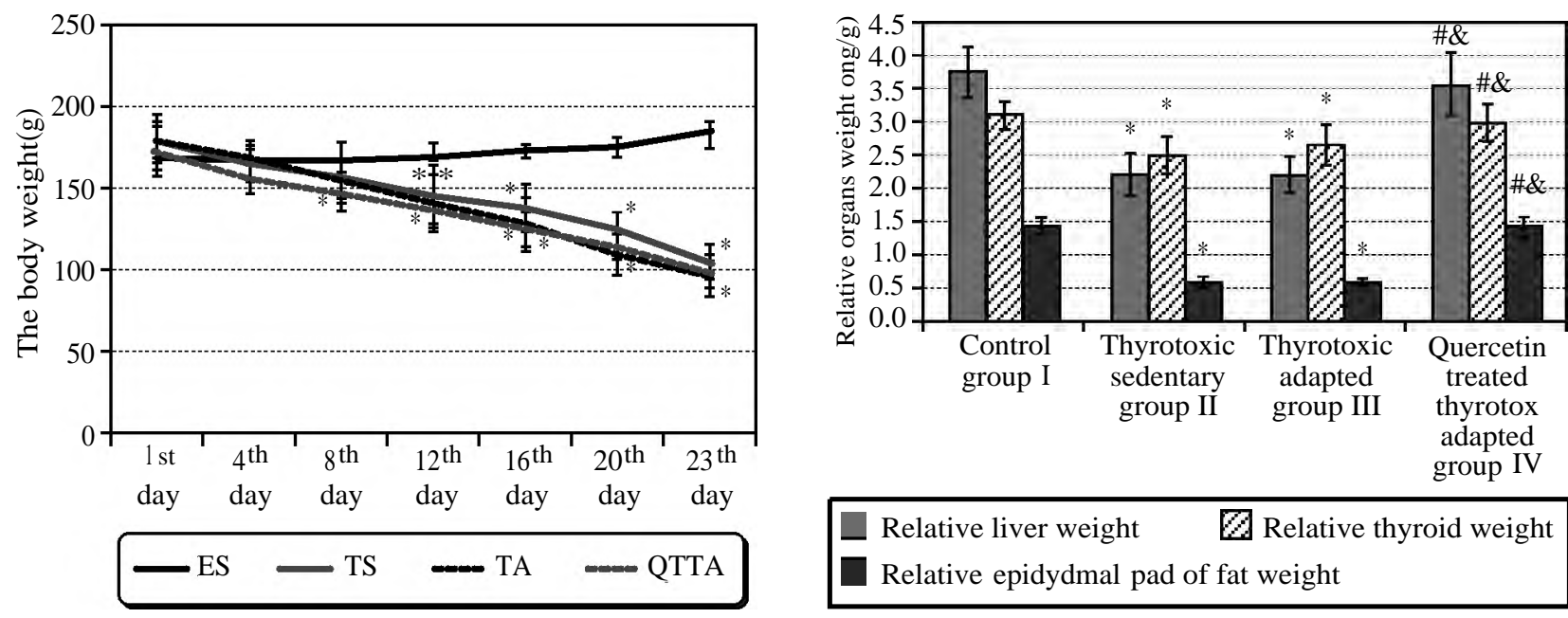

Relative liver weight $Q$ Relative thyroid weight

Relative epidydmal pad of fat weight

Fig. (1): Effect of thyroid status on body weight \& relative organs weight. 

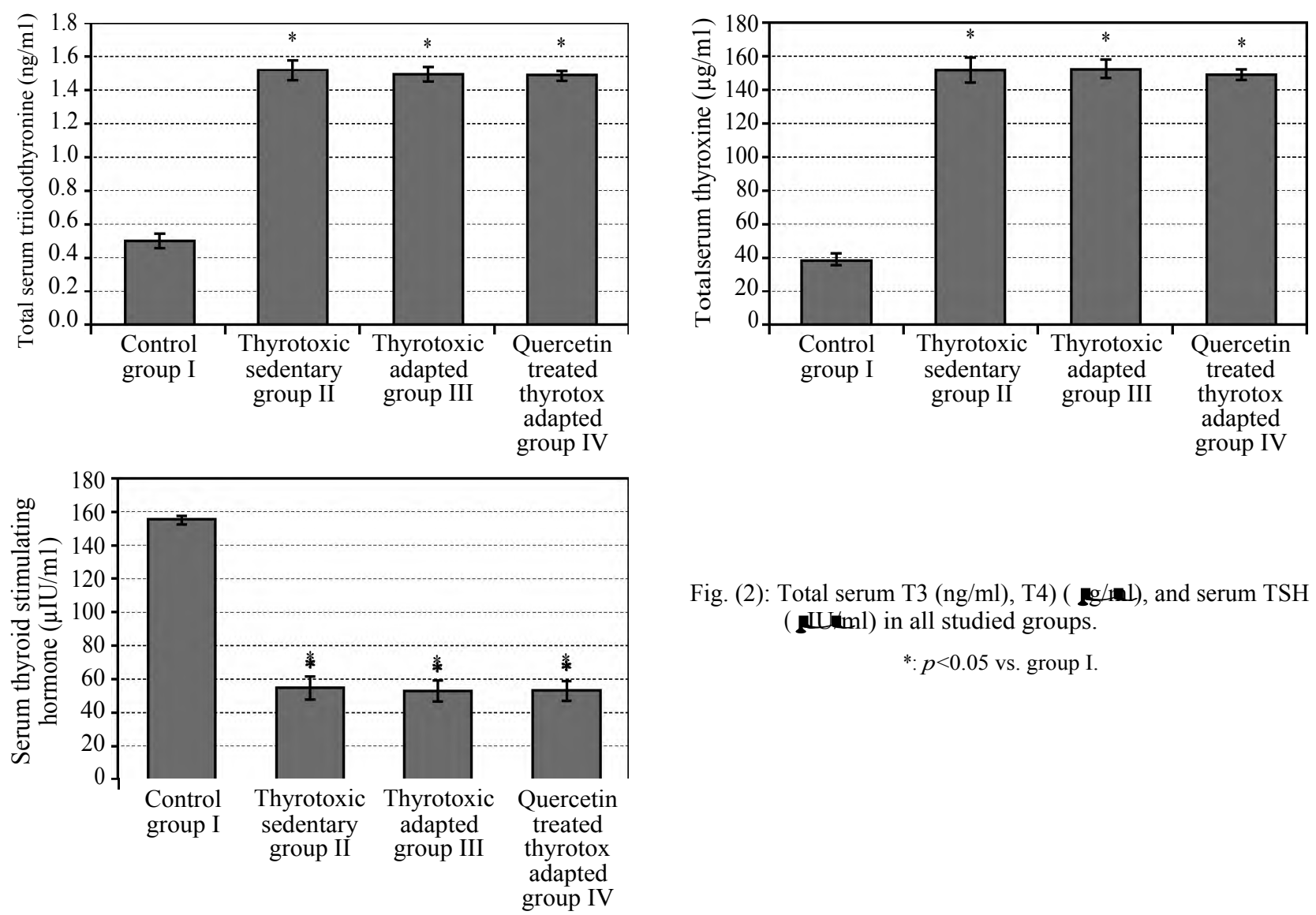

Fig. (2): Total serum T3 (ng/ml), T4) ( ( IUml) in all studied groups.
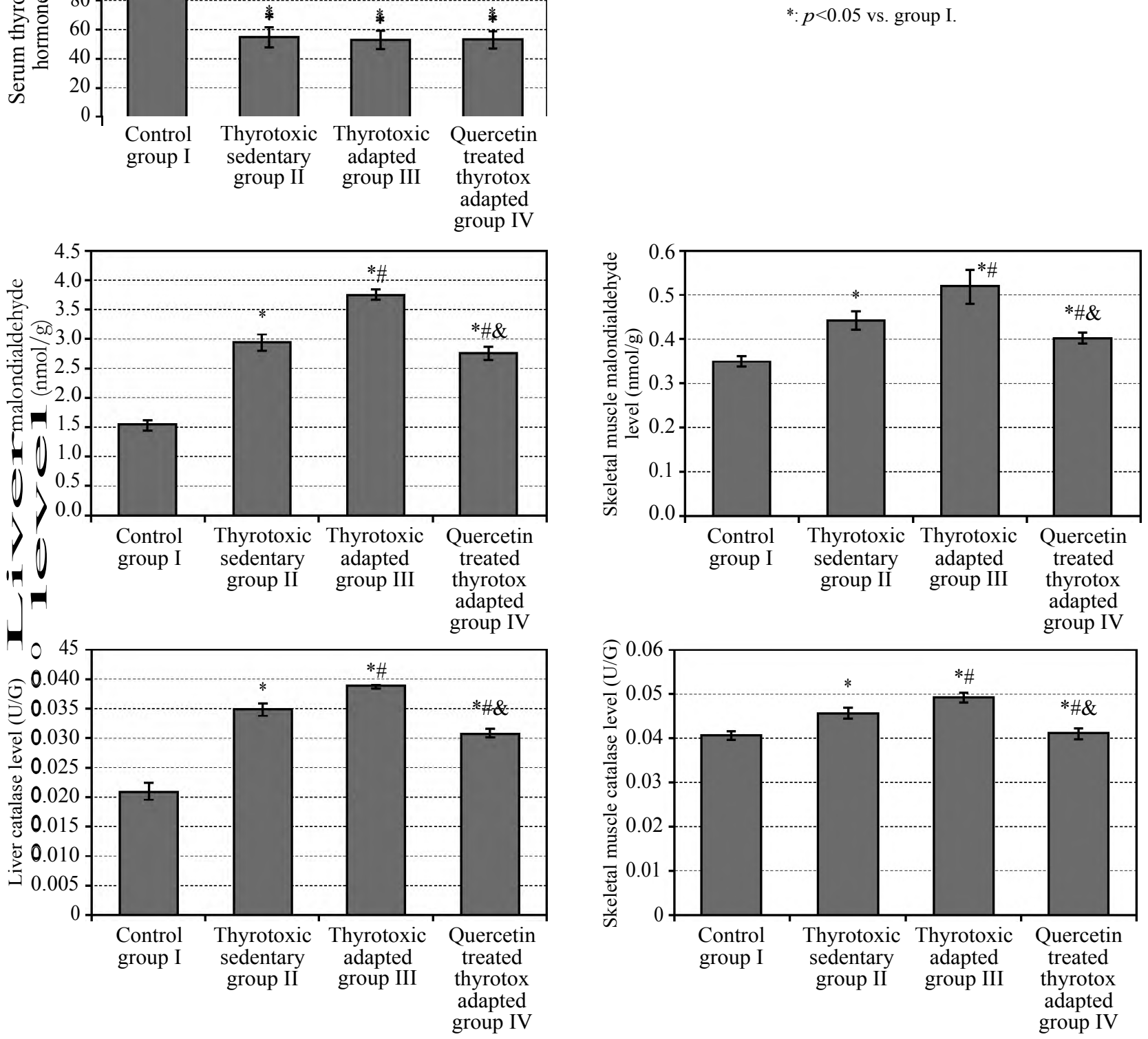

Fig. (3) 

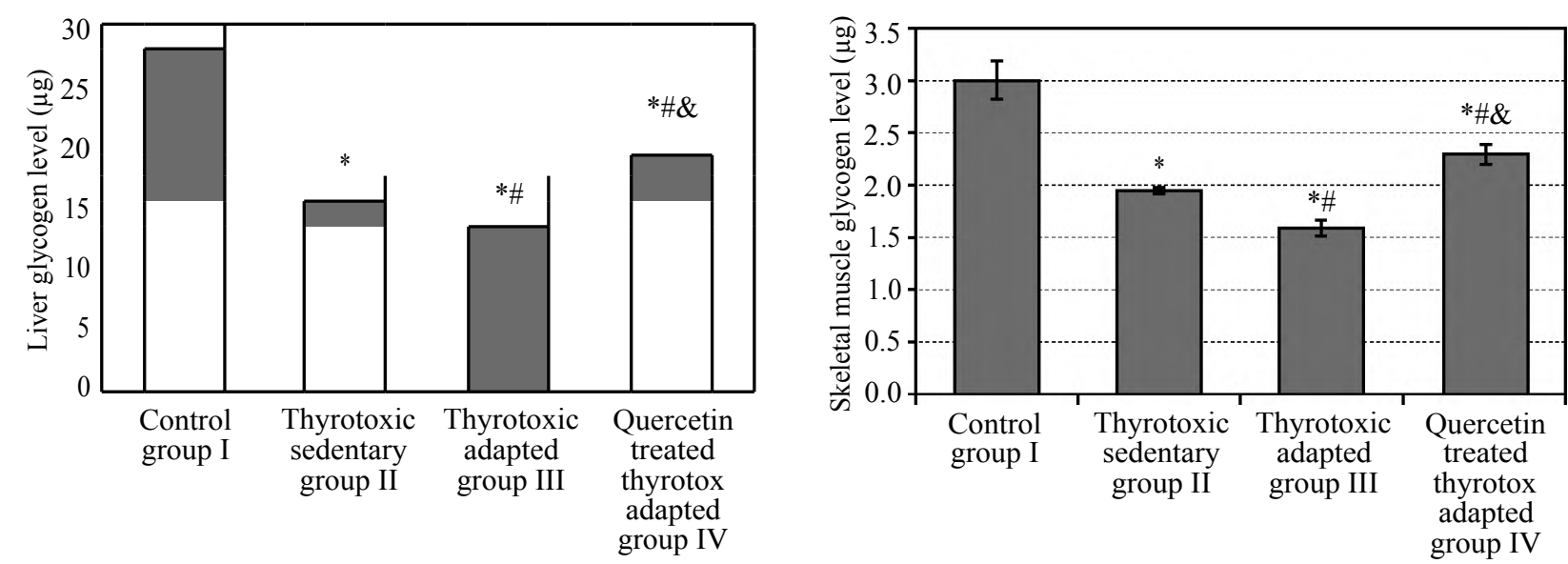

Fig. (4): Liver and skeletal muscle glycogen levels in all studied groups.

*: $p<0.05$ vs. group I. $\quad$ \#: $p<0.05$ vs. group III. $\quad \&: p<0.05$ vs. group IV.

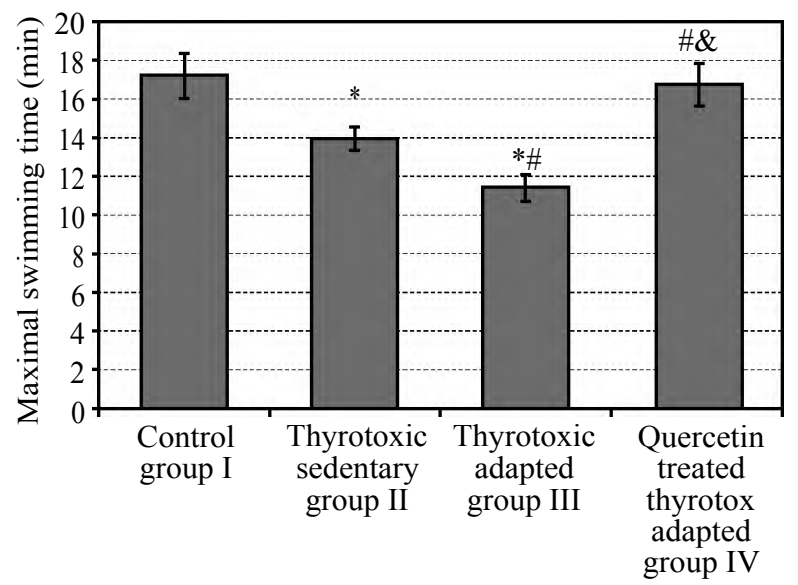

Fig. (5): Maximal swimming time ( $\mathrm{min}$ ) in all studied groups.

$*: p<0.05$ vs. initial weight in group I. $\quad \#: p<0.05$ vs. group III. $\&: p<0.05$ vs. group IV.

\section{Discussion}

The results of the present work revealed that all thyrotoxic groups showed significant decrease in the total body weight when compared to control group. While in thyrotoxic sedentary, and thyrotoxic adapted groups the relative liver weight, the relative thyroid weight, and the relative epididymal pad of fat weight showed significant decrease when compared to control group.

The significant decrease in total body weight, and relative organ weights is in agreement with the study of Peterson, et al., [17] who showed decrease in total body weight, the relative liver weight, the relative thyroid weight, and the relative epididymal pad of fat weight after induction of thyrotoxicosis.

The decrement in body weight could be explained by that hyperthyroidism accelerates the whole body protein turnover and catabolizes muscle tissue. This leads to muscle mass loss, which has long been known as an important clinical feature in thyrotoxic patients [18]. Another mechanism is reported by Mittag, et al. [19] who stated that hyperthyroidism exerts an important catabolic effects on adipose tissue. Thyroid Hormones (THs) stimulate both lipolysis and lipogenesis, however when their levels are increased, the net effect is fat loss. THs stimulate BMR by increasing production of ATP for metabolic processes and by generating and maintaining ion gradients. THs stimulate metabolic cycles including glucose, fat, and protein catabolism and anabolism, but these are little contributions to BMR [20]. THs affect key metabolic pathways that control energy balance by regulating the energy storage and expenditure. THs control metabolism primarily through their actions in the liver, skeletal muscle, white fat, brown fat, brain and pancreas [21].

Weight loss in patients with hyperthyroidism may be due to exaggerated thermogenesis that mediated by uncoupling of the oxidative phosphorylation caused by THs [22]. Weight loss in spite of increasing hunger can be contributed to the fact that either the calorie intake was not sufficient to tide over the exaggerated (BMR), or some other factors like adipocytokines might be mediating the weight loss that occurs in hyperthyroid patients [23].

However, quercetin treated thyrotoxic adapted group showed insignificant change in relative organ weights when compared to control group, but it showed significant increase when compared to thyrotoxic sedentary, and thyrotoxic adapted groups. The increase in relative organ weight after quercetin treatment explained by Lekic, et al. [24] 
who stated that flavonoids including quercetin have an important ameliorating effect on the hyperthyroidism and related organ damages caused by eltroxin, through their antioxidant effects.

The result also showed significant increase in serum T3 \& T4 levels, with significant decrease in serum TSH level in thyrotoxic sedentary, thyrotoxic adapted, and quercetin treated thyrotoxic trained groups when compared to control group. This is explained by Bowers, et al., [25] who stated that hypothalalmic pituitary thyroid axis mainly acts to keep normal circulating level of THs that is important for the biological function of all body tissues including cardiovascular regulation, liver function, brain development, bone, food intake, and energy expenditure between many others.

The result showed a significant increase in liver, skeletal muscle MDA, and catalase in all thyrotoxic groups when compared to euothyroid group. THs are the most important regulator of the oxidative metabolism and basal metabolic state. However, when their levels increase in hyperthyroidism they cause increase oxygen consumption, mitochondrial respiratory chain dysfunction, elevation of intracellular ATP consumption, and increased production of ROS. The extent of oxidative stress produced by THs differs widely between tissues, with the largest effects on the cell types which are more responsive to THs such as red oxidative muscle fibers, liver, heart, and lymphoid tissue [26]

The results also showed a significant increase in liver, skeletal MDA and catalase level in thyrotoxic adapted group when compared to thyrotoxic sedentary group. There are various mechanisms of intracellular and extracellular Reactive Oxygen Species (ROS) production in skeletal muscle during exercise. The primary mechanisms include NADPH oxidase, xanthine oxidase, NO synthase, and arachidonic acid release from cell membranes by phospholipase $\mathrm{A} 2$, whereas mitochondrial electron leak is suggested to contribute only during muscular contraction [27].

The result also showed significant decrease in liver, skeletal MDA and catalase level after quercetin treatment. Quercetin reduces tissue injury caused by oxidative stress by interfering with inducible nitric oxide (NO) synthase activity. The higher concentration of NO produced by NO synthase in macrophages can cause oxidative damage. So, the activated macrophages increase their simultaneous production of both nitric oxide and superoxide anions. NO reacts with free radicals, produc- ing high damaging peroxynitrite. Peroxynitrite can oxidize LDLs causing irreversible cell membranes damage. Quercetin causes scavenging of free radicals; therefore can no longer react with (NO), causing little damage. NO may be viewed as radical itself and can directly be scavenged by flavonoids [28].

Konrad, et al. [29] reported that quercetin has an enzyme inhibitory action that extends to phospholipases which catalyses the release of arachidonic acid from cell membranes phospholipids. Arachidonic acid considered as a key substrate for substances such as leukotrienes, thromboxane, and inflammatory prostaglandins. Quercetin inhibits Lipooxygenase and cyclooxygenase that catalyses the conversion of arachidonic acid to its metabolites.

The present work also showed a significant decrease in liver, and skeletal muscle glycogen in thyrotoxic sedentary, thyrotoxic adapted, quercetin treated groups when compared to control group.

Liver and skeletal muscles are the principal regulators of peripheral glucose homeostasis. The hyper-metabolic state of hyperthyroidism needs an increase in glucose metabolism for additional energy supply to the muscle. During thyrotoxicosis, insulin in muscle tissue cannot stimulate glycogen synthesis properly, resulting in an overall depletion of glycogen store. So the skeletal muscle glucose use is elevated to overcome the reduction in glycogen stores aiming to increases in oxidative and non-oxidative metabolic pathways [23]

Flamant, et al. [30] has been reported that in hyperthyroidism, the increased rates of glycolysis in skeletal muscle will lead to increased plasma lactate concentrations, increasing Cori-cycle activity. Increased Cori-cycle activity would consume a large amount of energy, since the resynthesis of glucose in the liver needs the expenditure of large amount of ATP than is produced from glycolysis in muscle.

The result also showed significant decrease in thyrotoxic adapted group when compared to thyrotoxic sedentary group. Muscle glycogen is recognized as the primary fuel source for the sustained contractile activity in human skeletal muscle. Muscle glycogen content is related to the physiological status it is degraded during exercise and re-synthesized during the periods of recovery [31]

While the results showed significant increase in liver and muscle glycogen in quercetin treated thyrotoxic adapted group when compared to thy- 
rotoxic adapted group. Quercetin modulates insulin sensitivity by up-regulating the expressions of glucose transporter and insulin receptor, also by inducing the glucose metabolism in peripheral tissues [32].

Zheng, et al. [33] reported that quercetin stimulated glucose uptake in cultured skeletal muscle by an insulin-independent mechanism including adenosine mono-phosphate-activated protein kinase (AMPK). AMPK is considered a key regulator of energy homeostasis of the whole body. AMPK activation of in primary culture of hepatocytes was shown to decrease the gene expression of gluconeogenesis enzymes and to inhibit hepatic glucose output. Hence, quercetin has the potential to decrease glucose production by liver. Finally, decreasing liver gluconeogenesis, glucose production by liver can also be improved by increasing the storage of glucose in the form of glycogen [34]

The results revealed that the thyrotoxic sedentary, thyrotoxic adapted groups showed a significant decrease in MST, while quercetin treated thyrotoxic adapted showed insignificant change when compared to control group. One of the primary effects of thyroid dysfunction is decrease tolerance to physical exercise, due to its implications including cardiovascular systems and the skeletal muscle. This interferes directly in the ability of patients to perform the daily activities, so decreasing his quality of life [35]. Cardiac ATPase composed of two heavy-chain proteins, alpha (a) and beta (b), and this enzyme is involved in the energy production for cells. The (a) chain has a high ability to dephosphorylate ATP, while the (b) chain has a low ability. The expression of the a-chain gene increases in the presence of $\mathrm{TH}$, so it improves the contractility of myocardium. However, this improvement in contractile force occurs only with slight elevation of TH level, as excessive levels of it induce catalysis of the contractile protein. So the hyperthyroid patients have exercise intolerance [26].

Various metabolic changes may be noticed in both hypothyroid and hyperthyroid patients. In hypothyroid state, fatigue is related to decreased action of THs. In the latter, the cause is mainly depletion of muscle energy substrate due to high metabolic demand [36].

The results also showed significant decrease in MST in thyrotoxic adapted group when compared to thyrotoxic sedentary group. Nathan, et al. [37] has demonstrated that exhaustive exercise causes oxidative stress, inflammatory response, and struc- tural damage to muscle cells, evidenced by an increase in the plasma activity of cytosolic enzymes, namely, Lactic Dehydrogenase (LDH) and Creatine Kinase (CK), so antioxidant supplementation such as quercetin seems to be a strategy to reduce or prevent tissues damage in active muscles.

Another study explained that quercetin can improve glycolytic flux, this demonstrated by its effect on blood lactate immediately after exhaustion. The elevated blood lactate levels were considered an indication of enhanced glycolysis and lactate production in the skeletal muscle. There are other possible causes could result in an increased lactate production as psycho-stimulant effects of quercetin might increase effort at high intensities [38]

\section{Conclusion:}

These findings highlight that Quercetin has antioxidant capability which attenuates the oxidative stress produced by both exercise and the induced hyperthyroidism. So we may use it as a protective drug in exercise intolerance that occurs in hyperthyroidism.

\section{References}

1- CHESTER A. RAY, CHARITY L. SAUDER, DANA M RAY and NISHIDA Y.: Effect of acute hyperthyroidism on blood flow, muscle oxygenation, and sympathetic nerve activity during dynamic handgrip. Physiol. Rep., 1 (1): e00011, 2013.

2- BHANJA S., SUBUDHI U., DAS K., PAITAL B. and CHAINY G.B.N.: "Alleviation of enhanced oxidative stress and oxygen consumption of 1-thyroxine induced hyperthyroid rat liver mitochondria by vitamin $\mathrm{E}$ and curcumin," Chemico-Biological Interactions, 173 (2): 105-14. 2008.

3- FERREIRAL E., SILVAL A.E., SERAKIDES R., GOMES A.E.S. and CASSALI G.D.: Model of induction of thyroid dysfunctions in adult female mice. Arq. Bras. Med. Vet. Zootec., 59 (5): 1245-9, 2007.

4- YAMADA T., MISHIMA T., SAKAMOTO M., SUGIYAMA M., MATSUNAGA S. and WADA M.: Myofibrillar protein oxidation and contractile dysfunction in hyperthyroid rat diaphragm, Journal of Applied Physiology, 102: 1850-5, 2007.

5- CASUSO R.A., MARTÍNEZ-LÓPEZ E.J., NORDSBORG N.B., HITA-CONTRERAS F., MARTÍNEZ-ROMERO R., CAÑUELO A., et al.: Oral quercetin supplementation hampers skeletal muscle adaptations in response to exercise training. Scand. J. Med. Sci. Sports, 24 (6): 920-7, 2014

6- CASUSO R.A., MARTÍNEZ-LÓPEZ E.J., HITACONTRERAS F., CAMILETTI-MOIRON D., MARTÍNEZ-ROMERO R., CAÑUELO A., et al.: The combination of oral quercetin supplementation and exercise prevents brain mitochondrial biogenesis Genes. Nutr., 9 (5): 420, 2014. 
7- GEREBEN B., MCANINCH E.A., RIBEIRO M.O. and BIANCO A.C.: Scope and limitations of iodothyronine deiodinases in hypothyroidism. Nat. Rev. Endocrinol., (11): 642-52, 2015.

8- MATSAKAS A., BOZZO C., CACCIANI1 N., CALIARO F., REGGIANIL C., MASCARELLO F., et al.: Effect of swimming on myostatin expression in white and red gastrocnemius muscle and in cardiac muscle of rats. Exp. Physiol., 91: 983-94, 2006.

9- DAS K., SUBUDHI U., PAITAL B., BHANJA S. and CHAINY G.B.N.: Alleviation of enhanced oxidative stress and oxygen consumption of 1-thyroxine induced hyperthyroid rat liver mitochondria by vitamin $\mathrm{E}$ and curcumin. Chemico-Biological Interactions, Vol. 173, No. 2, pp. 105-14, 2008.

10- RUSSELL J.C., LO S. and TAYLOR A.W.: Determination of glycogen in small tissue samples. Journal of Applied Physiology, 28: 234-6, 1970.

11- OHKAWA H., OHISHI N. and YAGI K.: Assay for lipid peroxides in animal tissues by thiobarbituric acid reaction. Anal. Biochem., 95 (2): 351-8, 1979.

12- MARTIN J.P. J.R., DAILEY M. and SUGARMAN E. Negative and positive assays of superoxide dismutase based on hematoxyli autoxidation. Archives of biochemistry and Biophysics, 255: 329-36, 1987.

13- JOHNSON PR, and HIRSCH J.: Cellularity of adipose depots in six strains of genetically obese mice. J. Lipid Res., 13 (1): 2-11, 1972.

14- BEHNKE A. and WILMORE J.H.: Evaluation and Regulation of Body Build and Composition. Prentice-Hall. Englewood Cliffs, N.J.; 48-52, 1974

15- De ARAUJO G.G., PAPOTI M., DOS REIS I.G., De MELLO M.A. and GOBATTO: CAShort and Long Term Effects of High-Intensity Interval Training on Hormones, Metabolites, Antioxidant System, Glycogen Concentration, and Aerobic Performance Adaptations in Rats. Front Physiol., 28 (7): 505. eCollection, 2016.

16- CASIMIRO-LOPES G., ALVES S.B., SALERNO V.P., PASSOS M.C., LISBOA P.C. and MOURA E.G.: Maximum acute exercise tolerance in hyperthyroid and hypothyroid rats subjected to forced swimming. Horm. Metab. Res., 40: 276-80, 2008.

17- PETERSON M.E., CASTELLANO C.A. and RISHNIW M.: Evaluation of Body Weight, Body Condition, and Muscle Condition in Cats with Hyperthyroidism. J. Vet. Intern. Med., 30 (6): 1780-9, 2016.

18-BIONDI B. and WARTOFSKY L.: Treatment With Thyroid Hormone. Endocrine Reviews, 35 (3): 433-512, 2014.

19- MITTAG J., LYONS D.J., SALLSTROM J., VUJOVIC M., DUDAZY-GRALLA S., WARNER A., et al.: Thyroid hormone is required for hypothalamic neurons regulating cardiovascular functions. J. Clin. Invest., 123: 509-16, 2013.

20- BARALDI D., CASALI K., FERNANDES R.O., CAMPOS C., SARTÓRIO C., CONZATTI A., et al.: The role of AT 1-receptor blockade on reactive oxygen species and cardiac autonomic drive in experimental hyperthyroidism. Autonomic Neuroscience: Basic and Clinical, 177 (2): 163-9, 2013.
21- WARING A.C., RODONDI N., HARRISON S., KANAYA A.M., SIMONSICK E.M., MILJKOVIC I., et al.: Thyroid function and prevalent and incident metabolic syndrome in older adults: The health, ageing and body composition study. Clin. Endocrinol. (Oxf), 76: 911-18, 2012.

22- BARAL R. and PETERSON M.E.: Thyroid gland disorders In: Little S.E., editor., ed. The Cat: Clinical Medicine and Management. Philadelphia: Elsevier Saunders, 571-92, 2012.

23- SALVATORE D., SIMONIDES W.S., DENTICE M., ZAVACKI A.M. and LARSEN P.R.: Thyroid hormones and skeletal muscle-new insights and potential implications. Nat. Rev. Endocrinol., 10: 206-14, 2014.

24- LEKIC N., CANOVA N.K., HORINEK A. and FARGHALI H.: The involvement of heme oxygenase 1 but not nitric oxide synthase 2 in a hepatoprotective action of quercetin in lipopolysaccharide-induced hepatotoxicity of Dgalactosamine sensitized rats. Fitoterapia, 87: 20-6, 2013.

25- BOWERS J. TERRIEN J., CLERGET-FROIDEVAUX M.S., GOTHIÉ J.D., ROZING M.P., WESTENDORP R.G.J., et al.: Thyroid Hormone Signaling and Homeostasis During Aging. Endocrine Reviews, 34 (4): 556-89, 2013.

26- ELNAKISH M.T., SCHULTZ E.J., GEARINGER R.L., SAAD N.S., RASTOGI N., AHMED A.A., et al.: Differential involvement of various sources of reactive oxygen species in thyroxin-induced hemodynamic changes and contractile dysfunction of the heart and diaphragm muscles. Free Radical Biology and Medicine, 83: 252-61, 2015.

27- SAKELLARIOU G.K., VASILAKI A., PALOMERO J., KAYANI A., ZIBRIK L., MCARDLE A., et al.: Studies of mitochondrial and nonmitochondrial sources implicate nicotinamide adenine dinucleotide phosphate oxidase(s) in the increased skeletal muscle superoxide generation that occurs during contractile activity. Antioxid Redox Signal., 18: 603-21, 2013.

28- SUN C., WANG H., WANG D., CHEN Y., ZHAO Y., and XIA W.: Using an FFQ to assess intakes of dietary flavonols and flavones among female adolescents in the Suihua area of northern China. Public Health Nutr., 18: 632-9, 2015.

29- KONRAD M., and NIEMAN D.C.: Evaluation of quercetin as a countermeasure to exercise-induced physiological stress. In: Lamprecht M., editor. Source Antioxidants in Sport Nutrition. CRC Press; Boca Raton, FL, USA, Chapter 10, 2015.

30- FLAMANT F., and GAUTHIER K.: Thyroid hormone receptors: The challenge of elucidating isotype-specific functions and cell-specific response. Biochim. Biophys. Acta., 1830: 3900-7, 2013.

31- BURKE L.M., VAN LOON L.J., and HAWLEY J.A.: Post-exercise muscle glycogen resynthesis in humans. J. Appl. Physiol., 122 (5): 1055-67, 2016.

32- FORTUNATO R.S., BRAGA W.M., ORTENZI V.H., RODRIGUES D.C., ANDRADE B.M., MIRANDAALVES L., et al.: Sexual dimorphism of thyroid reactive oxygen species production due to higher NADPH oxidase 4 expression in female thyroid glands. Thyroid., 23 (1): $111-9,2013$ 
33- ZHENG S.Y., LI Y., JIANG D., ZHAO J. and GE J.F.: Anticancer effect and apoptosis induction by quercetin in the human. Mol. Med. Rep., 5: 822-6, 2012.

34- KIM J.H., KANG M.J., CHOI H.N., JEONG S.M., LEE Y.M. and KIM J.I.: Quercetin attenuates fasting and postprandial hyperglycemia in animal models of diabetes mellitus. Nutr. Res. Pract., 5: 107-11, 2011.

35- ASPROMONTE N., MONITILLO F., PUZZOVIVO A., VALLE R., CALDAROLA P., and IACOVIELLO M.: Modulation of cardiac cytochrome P450 in patients with heart failure. Expert Opinion on Drug Metabolism and Toxicology, 10 (3): 327-39, 2014.

36- SELMER C., OLESEN J.B., HANSEN M.L., VON KA-
PPELGAARD L.M., MADSEN J.C., HANSEN P.R., et al.: Subclinical and overt thyroid dysfunction and risk of all-cause mortality and cardiovascular events: A large population study. J. Clin. Endocrinol. Metab., 99: 237282, 2014.

37- NATHAN C. and CUNNINGHAM-BUSSEL A.: Beyond oxidative stress: An immunologist's guide to reactive oxygen species. Nat. Rev. Immunol., 13: 349-61, 2013.

38- WIRTH C.D., BLUM M.R., DA COSTA B.R., BAUMGARTNER C., COLLET T.H., MARCO MEDICI, et al.: Subclinical thyroid dysfunction and the risk for fractures: A systematic review and meta-analysis. Ann. Intern. Med., 5 (161): 189-99, 2014.

\section{تآثير الكربيتين على تحمل التمارين فى زيادة هرمون الغدة الدرقية المستحدث في ذكور الجمارين فرذان البيضاء هرون اليضاء}

الهدف من البحث: تم إجراء هذا البحث لدراسة تآثير الكيربيتين على مماربة التمارين في حالات فرط نشاط الغدة الدرقية المستحدث في ذكور الجرذان البيضاء.

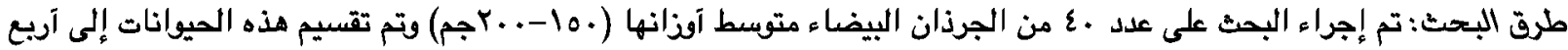

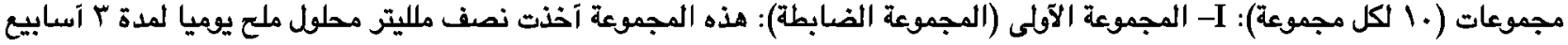

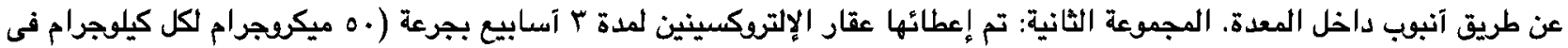

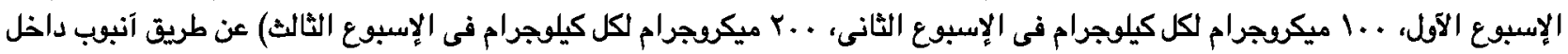

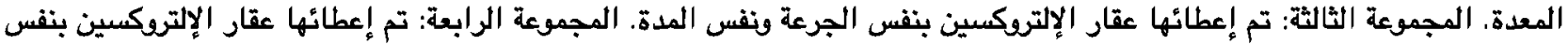

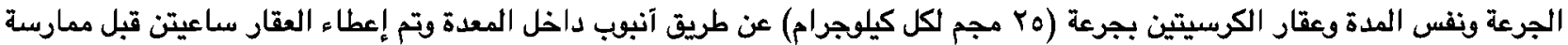

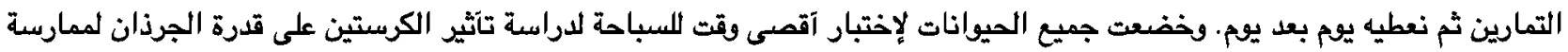
التمارين. بالإضافة إلى إجراء لودة تآقلم على السباحة لمدة يومين لكل من المجموعتين الثالثة والرابعة قبل إجراء الإختبار.

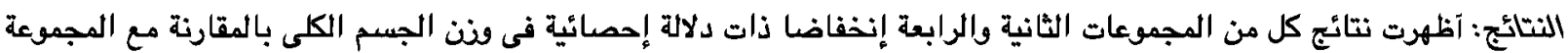

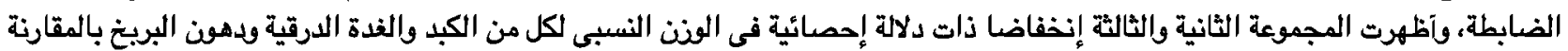

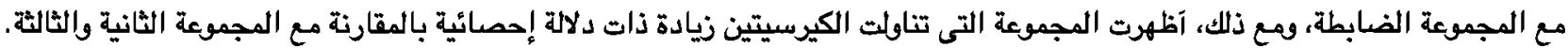
كما آظهرت المجموعات الثانية والثالثة والرابعة زيادة ذات دلالة إحصائية في مستصى المصل (TSH)، وإنخفاض ذات ذات دلالة إحصائية في مستصى

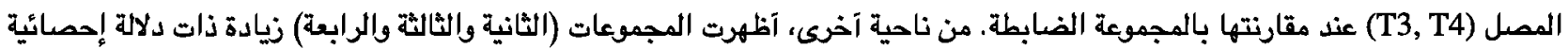

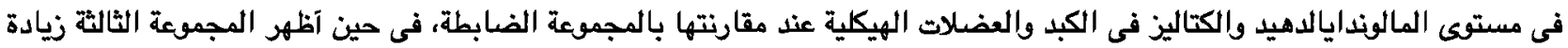

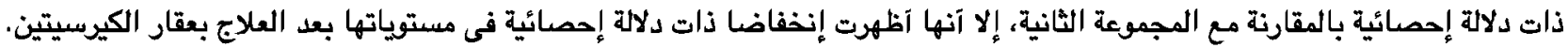

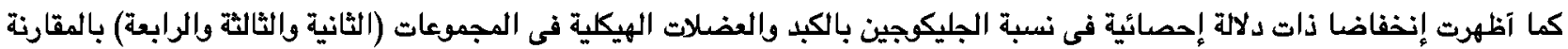

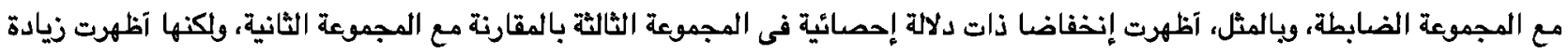

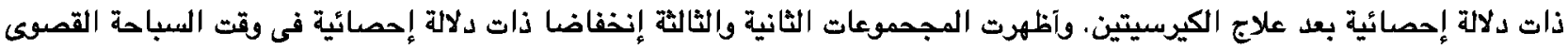

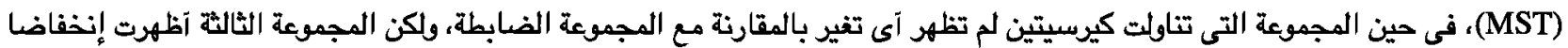

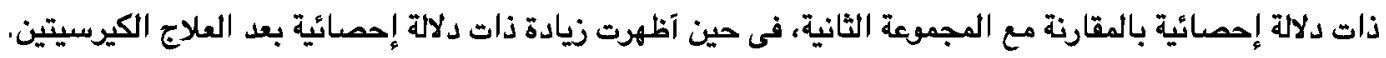

الإستتاج: نستتج من نتائج هذا البحث آن الكيربيتين يلعب دور فعالا فى تصسين صعوبة ممارسة التمارين الذى يحدث من فرط نشاط الغدة الدرقية خلال تآثيره كمضاد للآكسدة. 